YOBLICZA $12 / 2020$

https://doi.org/10.19195/2083-5345.12.15

PATRYCJA KRYSIAK

ORCID: 0000-0001-9691-4525

Uniwersytet Wrocławski

Instytut Filologii Romańskiej, Zakład Translatologii

AGNIESZKA MAŁOCHA-KRUPA

ORCID: 0000-0002-8698-2812

Uniwersytet Wrocławski

Instytut Filologii Polskiej, Zakład Współczesnego Języka Polskiego

\title{
Feminatywum, feminatyw, nazwa żeńska, żeńska końcówka - problemy terminologiczne
}

\begin{abstract}
Abstrakt
Celem artykułu jest przedstawienie różnych zakresów funkcjonowania i odmiennych sposobów rozumienia terminów najczęściej pojawiających się w polskim piśmiennictwie w odniesieniu do rzeczowników rodzaju żeńskiego nazywających kobiety. Swoisty chaos terminologiczny rodzi się z jednej strony z różnych, częstokroć niezgodnych definicji nazw żeńskich/feminatywów przytaczanych przez badaczy i badaczki języka, $\mathrm{z}$ drugiej zaś - z obecności również w kręgach nieakademickich kontrowersji i sporów wokół zagadnienia językowej niewidzialności kobiet, które owocują pojawianiem się w komunikacji publicznej potocznych użyć czy wręcz wariantów naukowych terminów. Autorki przybliżają wypracowany we wrocławskim ośrodku badawczym sposób rozumienia terminu nazwy żeńskie i charakteryzują go na tle innych koncepcji; przedstawiają przy tym założenia terminologiczne leżące u podstaw Słownika nazw żeńskich polszczyzny (2015). W artykule omówiono także kwestię ewolucji użyć terminu naukowego feminatywum i jego przenikanie do polszczyzny ogólnej, jak również pojawiające się w obiegu potocznym innowacje nazewnicze (żeńska końcówka).
\end{abstract}

Słowa kluczowe: feminatywum, feminatyw, nazwa żeńska, terminologia, lingwistyka płci.

\section{Wprowadzenie}

We współczesnej rzeczywistości językowej — kiedy to dyskusje na temat sposobu nazywania kobiet (ze względu na wykonywany zawód, posiadany tytuł, piastowane stanowisko czy funkcję publiczną) nie ograniczają się wyłącznie do łamów czaso- 
pism językoznawczych i sal plenarnych na konferencjach naukowych, kiedy angażuje się w nie opinia publiczna, a więc użytkownicy i użytkowniczki języka mający różną świadomość terminologiczną i wiedzę językoznawczą — odnosimy wrażenie, że terminy feminatywum, feminatyw, nazwa żeńska czy wreszcie żeńska końcówka są traktowane jako równoznaczne i że używa się ich w zasadzie wymiennie. Trzeba jednak zaznaczyć, że choć dziś zdają się funkcjonować niejako równolegle, wybór każdego z nich może nieść nieco inne konsekwencje — zarówno dla metodologii prowadzonych badań (na gruncie polszczyzny nie ma całkowitej zgody wśród językoznawców odnośnie do zakresu tych terminów), jak i dla ich recepcji (tu do czynienia mamy z opozycją naukowej tradycji i rozumienia potocznego). Niniejszy artykuł zawiera przegląd różnych sposobów funkcjonowania pojęć zaanonsowanych w tytule. Przybliżamy właściwy wrocławskiemu ośrodkowi sposób definiowania nazw żeńskich leżący u podstaw prowadzonych tam już od ponad dekady badań nad słowotwórstwem żeńskoosobowym, a także odnosimy się do terminów wobec nich synonimicznych albo quasi-synonimicznych.

\section{Założenia redakcyjne Słownika nazw żeńskich polszczyzny}

Od 2010 roku w Instytucie Filologii Polskiej Uniwersytetu Wrocławskiego, w Zakładzie Współczesnego Języka Polskiego, kierowanym od 1998 roku przez panią profesor Irenę Kamińską-Szmaj, działa zespół leksykograficzny rejestrujący zasoby słowotwórstwa feminatywnego. Owocem prac ekscerpcyjnych zespołu, obecnie funkcjonującego już oficjalnie jako Pracownia Badań nad Słowotwórstwem Nazw Żeńskich, stały się: publikacja Słownika nazw żeńskich polszczyzny (2015), a niedługo później książki habilitacyjnej Feminatywum w uwikłaniach językowo-kulturowych (2018), obrony dwóch doktorantek (Patrycji Krysiak - Nazwy żeńskie we współczesnej leksykografii polskiej i francuskiej i Katarzyny Hołojdy-Mikulskiej Problem z potocznościa nazw żeńskich $w$ polszczyźnie XXI wieku), a także powstanie wielu artykułów naukowych oraz prac dyplomowych. Pani profesor Irena Kamińska-Szmaj życzliwie tym badaniom nie tylko sprzyjała, lecz także je inspirowała szczególnie w czasie licznych dyskusji: i tych mniej formalnych w instytutowej Rospondówce, $w$ gabinecie 112, i tych na zebraniach swojego Zakładu, w którym wielką wagę przywiązywano między innymi do zagadnień edukacji antydyskryminacyjnej i dyskursu równościowego. Dzięki oferowanym przez Zakład zajęciom dydaktycznym zawiązał się zespół badawczy, w którym narodziła się między innymi koncepcja leksykograficzna Stownika nazw żeńskich polszczyzny (dalej: SNŻP) (Małocha-Krupa 2018b; Śleziak 2018; Krysiak 2020).

Już na samym początku prac nad SNŻP nazwy żeńskie zostały przez wrocławskie badaczki utożsamione z pojęciem feminatywum, rozumianym wąsko - słowotwórczo - jako kategoria słowotwórcza obejmująca rzeczowniki nazywające kobietę, mające wyznacznik morfologiczny żeńskości, będące najczęściej derywatami 
sufiksalnymi lub paradygmatycznymi pochodzącymi od męskiej podstawy słowotwórczej. Podobnie zresztą zdefiniował nazwy żeńskie i powiązał to pojęcie z terminem kategorii feminatywum Marek Łaziński (2006: 246), dla którego nazwy żeńskie to „rzeczowniki nazywające kobiece zawody i funkcje, najczęściej derywowane od nazw męskich z sufiksem kategorii feminativum lub bezpośrednio od czasowników z sufiksem złożonym kategorii wykonawców czynności”.

Wrocławskie rozumienie terminu nazwa żeńska/feminatywum jest zatem na wskroś pochodną ustaleń i tendencji polskiego słowotwórstwa, które nazwy żeńskie utożsamia z kategorią słowotwórczą istniejącą obok nazw deminutywnych, augmentatywnych, ekspresywnych i nazw istot młodych (zob. Grzegorczykowa 1999). Wykładnikiem morfologicznym żeńskości jest wykładnik słowotwórczy.

Ostatecznie zgromadzone w SNŻP leksemy to:

takie formy językowe, które: są nazwami kobiet (aktualizowanymi w funkcji niezdrabniającej) oraz spełniają przynajmniej jeden z warunków:

(1) eksplikują wyznacznik morfologiczny (przyrostek) żeńskości: chrześniacz-ka, zwyciężcz-yni;

(2) zazwyczaj pochodzą od podstaw słowotwórczych męskoosobowych: handlarz $\rightarrow$ handlarka, handlowiec $\rightarrow$ handlowcz-yni (jednakże część z nich nie wywodzi się słowotwórczo od męskoosobowych podstaw, np. gorseciarka, sufrażystka, ze względu na to, że zakres pojęciowy, jaki wyznaczały, był postrzegany i wartościowany w kulturze polskiej jako prymarnie odnoszony do sfer bliższych kobietom, a zatem nie pojawiły się w dawnym zwyczaju społecznym takie rzeczowniki jak: ${ }^{*}$ gorseciarz, ${ }^{*}$ sufrażysta). (SNŻP: 11)

Dla zespołu leksykograficznego najcenniejszymi jednostkami leksykalnymi były przede wszystkim nazwy żeńskie niepotoczne i niewulgarne, niebędące konstrukcjami analitycznymi. Nie objęto ekscerpcją również nazw mieszkanek miejscowości, regionów i państw, nazw ekspresywnych pochodnych od innych nazw żeńskich (zarejestrowane zostało na przykład hasło mama, ale już nie jego pochodne: mamusia, mamunia, maminka, mamcia) oraz, co oczywiste, rzeczowników z przyrostkiem -ka w funkcji niefeminatywnej (na przykład drwalka jako 'praca w drwalni', listonoszka jako 'torebka').

Należy też podkreślić, że pochodną przyjętych założeń metodologicznych była decyzja o nieuwzględnianiu w SNŻP masculinum występującego w referencji wspólnogatunkowej (typu ta profesor, ta premier) oraz analityzmów (typu pani profesor, pani premier).

\section{Feminatywum, nazwa żeńska - wymienność terminów i ich zakres}

Badaczki wrocławskie utożsamiły nazwy żeńskie z pojęciem feminatywum. To ostatnie jawi się jako szczególnie trafne i wygodne do opisu żeńskości w języku - tym bardziej że znajduje zastosowanie w badaniach porównawczych polszczyzny i innych języków z kategorią rodzaju gramatycznego i rozpoznawane jest w wielu różno- 
języcznych pracach z dziedziny lingwistyki płci. Współcześnie w polskich badaniach forma liczby mnogiej feminatywa jest konkurencyjna wobec tradycyjnego, niemającego obcojęzycznego rodowodu i niekoniecznie motywowanego poglądem o androcentrycznym charakterze zjawisk językowych, terminu nazwy/formacje/struktury żeńskie - stosowanego przez polskich językoznawców od początków XX wieku (por. „Poradnik Językowy” 1906, nr 4: 55; „Poradnik Językowy” 1907, nr 6-7: 95; Doroszewski 1928: 58-72, 131, 221; Doroszewski 1962: 607-608; Grzegorczykowa, Puzynina 1979; Żarski 1992; Jadacka 2001; Karwatowska, Szpyra-Kozłowska 2005). Nazwa żeńska we wskazanych opracowaniach była właśnie utożsamiana ze współczesnym rozumieniem pojęcia feminatywum (jako formacji słowotwórczej z przyrostkiem żeńskości) i do tej tradycji definiowania odwołują się między innymi redaktorki SNŻP i autorki wrocławskich opracowań (Małocha-Krupa 2018a, 2018b; Śleziak 2018; Hołojda-Mikulska 2019; Krysiak 2020), stosując terminy nazwy żeńskie i feminatywa zamiennie.

Jeśli natomiast chodzi o zakres i rozumienie tych pojęć, opisane i przyjęte podczas prac redakcyjnych nad SNŻP założenia tylko częściowo odbiegają od tradycji językoznawczego rozumienia nazw żeńskich. Choć, jak wskazałyśmy wcześniej, typowe dla polskiego językoznawstwa jest opisywanie nazw żeńskich z perspektywy słowotwórczej, wielu badaczy nie uchyla się przed ujmowaniem tego zjawiska językowego z perspektywy będącej skrzyżowaniem trzech podsystemów: słowotwórstwa oraz fleksji i składni. W Gramatyce współczesnego języka polskiego (Grzegorczykowa 1999: 422) w zakres terminu nazwy żeńskie włączono bowiem nie tylko formacje sufiksalne i paradygmatyczne, lecz także te, które „uzyskują żeńskość przez zmianę rodzaju gramatycznego i wprowadzenie nieodmienności”.

Podobnie o tak zwanych homonimicznych nazwach żeńskich pisał Piotr Żmigrodzki (2008: 172-173), który na przykładzie form typu redaktor, dyrektor definiował je jako „leksemy równokształtne z nazwami tytułów, zawodów i stanowisk używanych $\mathrm{w}$ odniesieniu do mężczyzn, ale występujące w zdaniu z żeńskimi formami czasowników i przymiotników i mające pełny synkretyzm w zakresie przypadka w liczbie pojedynczej”. W ostatnich dekadach podkreśla się, że tego typu nazwy są niemal koniecznym składnikiem formuł adresatywnych, gdyż funkcja tytularna blokuje derywację żeńską (Łaziński 2006: 273). W badaniach wrocławskich analityzmy i nazwy pierwotnie męskoosobowe $\mathrm{z}$ unieruchomioną fleksją nie są jednak uważane za nazwy żeńskie - odpowiednim terminem byłyby w ich przypadku co najwyżej nazwy kobiet (Horodeńska-Ostaszewska 2006; Krysiak 2020: 52) czy nominacje kobiet (Małocha-Krupa 2018a).

Zaproponowane w SNŻP ujęcie, choć nie odbiega od językoznawczej szlachetnej tradycji końca XIX wieku i pierwszej połowy XX wieku, stało się przedmiotem dyskusji w środowisku językoznawczym, między innymi w czasie międzynarodowej konferencji „Glosa do leksykografii - a Gloss on Lexicography: Między teorią a praktyką. Metody współczesnej leksykografii” (Instytut Języka Polskiego Uniwer- 
sytetu Warszawskiego, 22-23 września 2016 roku) ${ }^{1}$. Redaktorki SNŻP uznały jednak, że ów węższy (wrocławski) zakres rozumienia i ekscerpowania nazw żeńskich (feminatywów) jest istotny ze względu na to, że: 1. lepiej odpowiada potrzebom społecznym na dyskutowaną w obiegu publicznym problematykę nazw żeńskich; 2. w świadomości społecznej nazwa żeńska to struktura sufiksalna/paradygmatyczna, nie zaś analityzm czy forma generyczna. Przekonują o tym dyskusje na zajęciach i ankiety przeprowadzane wśród studentów i studentek polonistyki I roku UWr (jeszcze przed kursem słowotwórstwa) oraz liczne pytania językoznawcze o nominację kobiet napływające do redaktorek SNŻP. Osoby zwracające się z pytaniami o poradę formułują ją zwykle według skryptu „Jak utworzyć (derywować) rzeczownik rodzaju żeńskiego nazywający kobietę, która jest/zajmuje się X?". Społeczne rozumienie terminu nazwy żeńskie odzwierciedlone jest także w potocznym sformułowaniu żeńskie końcówki, o którym będzie mowa w dalszej części opracowania - użytkownicy i użytkowniczki polszczyzny identyfikują przedmiot niezliczonych debat przede wszystkim ze zjawiskami słowotwórczymi, z eksplikującymi żeńskość afiksami, a nie $\mathrm{z}$ unieruchomieniem fleksyjnym.

W zespole redakcyjnym SNŻP zakres terminu nazwy żeńskie/feminatywa został zatem znacznie ograniczony, biorąc pod uwagę morfologię ekscerpowanych nazw. Jednocześnie jednak, co należy również podkreślić, zakres ten został rozszerzony pod względem semantycznym. W wielu publikacjach językoznawców opisujących kategorię rodzaju w języku polskim do nazw żeńskich zaliczają się bowiem wyłącznie rzeczowniki nazywające kobiece zawody i funkcje (por. przytaczana definicja Łazińskiego). Niektórzy badacze dokonują takiego ograniczenia referencjalnego terminu wprost, inni natomiast nie podają wprawdzie żadnej definicji zakresowej nazw żeńskich, lecz temat funkcji i tytułów niejako wysuwa się u nich na pierwszy plan, a inne określenia kobiet bywają mniej uwzględniane w opracowaniach problemu asymetrii rodzajowo-płciowych w języku (Klemensiewicz 1957; Kupiszewski 1967; Batko-Tokarz 2012: 187; Woźniak 2014; Grochowska, Wierzbicka 2015; Krysiak 2020: 53). To zawężenie tematyczne i ograniczenie referencji pojęcia nazwy żeńskie do nazw zawodów, tytułów i funkcji publicznych, z pominięciem innych nazw wykonawców czynności, nosicieli cech czy nazw odmężowskich, jest zresztą typowe nie tylko dla polskich badań, lecz także między innymi dla językoznawstwa francuskiego (Krysiak 2020: 53).

Właśnie opublikowana, najnowsza monografia Jolanty Szpyry-Kozłowskiej, zatytułowana Nianiek, ministra i japonki. Eseje o języku i płci (2021) - zauważmy - proponuje innowacyjną interpretację analizowanych pojęć. Autorka, podejmując problematykę osobowych nazw żeńskich, polemizuje między innymi z powszechnym przekonaniem, że zawsze pochodzą one od nazw męskich; wykazuje ich możliwą wielomotywacyjność - i co najważniejsze dla naszych rozważań - propo-

1 Por. tom pokonferencyjny Między teoriq a praktyką. Metody współczesnej leksykografii, red. M. Bańko, H. Karaś, Warszawa 2018. 
nuje innowacyjne rozumienie feminatywum (skądinąd w całej książce operuje też określeniem feminatyw, dotąd rzadko w lingwistyce spotykanym), traktując je ,jako kategorię nie tyle słowotwórczą, co semantyczną, której desygnaty zawierają w sobie pierwiastek »istoty żeńskiej «" (Szpyra-Kozłowska 2021: 51). Przyjmuje tak ze względu na to, że „wykluczanie określeń kobiet z definicji feminatywów z powodu ich znaczenia, struktury morfologicznej i składniowej, pochodności czy też ich rodzaju gramatycznego nie jest uzasadnione, ponieważ każda taka decyzja nosi znamiona arbitralności” (Szpyra-Kozłowska 2021: 51). Do niezwykle produktywnego zbioru nazw żeńskich/feminatywów włącza więc „wszystkie określenia żeńskich istot żywych (lub fikcyjnych typu Królewna Śnieżka, Śpiąa Królewna, Czerwony Kapturek, Zosia Samosia)". Przyjęcie kryterium semantycznego wydaje się szczególnie trafne, gdyż mieści w sobie wszystkie te nominacje kobiet/dziewcząt, które nie mają wykładnika żeńskości, na przykład babsztyl, podlotek, dziewczę, miss, bądź są wyrażeniami syntaktycznymi, na przykład babcia klozetowa czy house menedżerka.

Tymczasem przykładem łączenia kryterium semantycznego i strukturalnego w ustalaniu zakresu terminu nazwy żeńskielfeminatywa są rozstrzygnięcia przyjęte w monografii Patrycji Krysiak Nazwy żeńskie we wspótczesnej leksykografii polskiej i francuskiej (2020). Kierując się założeniami obecnymi już w innych pracach wrocławskich (między innymi SNŻP), lecz starając się również opracować spójne kryteria analizy polskiego i francuskiego materiału leksykalnego, autorka wymienia warunki, które muszą spełniać określenia kobiet, aby zostały przez nią zakwalifikowane jako nazwy żeńskie. Są to

rzeczowniki o bezdyskusyjnie żeńskim rodzaju gramatycznym, desygnujące wyłącznie kobiety, niederywowane (jak np. matka, córka, lesbijka), derywowane od podstaw słowotwórczych męskoosobowych za pomocą sufiksów lub formantu paradygmatycznego (lekarka, zwyciężczyni, handlarka, przewodnicząca) oraz formacje niewywodzące się słowotwórczo od podstaw męskoosobowych (przedszkolanka, sufrażystka). (Krysiak 2020: 114)

\section{Inne nominacje: feminatyw, żeńska końcówka}

$\mathrm{Na}$ coraz lepszą adaptację pojęcia feminatywum do systemu polszczyzny wskazuje ewolucja jego użyć od form nieustabilizowanych, mających charakter cytatu (feminativum, feminativa, feminatiwa — zob. Kreja 1964; Żarski 1992; Łaziński 2006), przez formy stosowane między innymi w ośrodku wrocławskim, pojawiające się w opisach założeń metodologicznych SNŻP (feminatywum, feminatywa), lecz także na przykład w pracach: Anny Piotrowicz i Małgorzaty Witaszek-Samborskiej (2015), Jolanty Szpyry Kozłowskiej (2019; w druku) czy Ewy Woźniak (2020), po stosunkowo niedawno powstałą innowację gramatyczną, zdobywającą coraz większą popularność zarówno w dyskursie akademickim, jak i w debatach publicznych, nacechowaną jednak publicystycznie (feminatyw, feminatywy). O popularności tej ostatniej świadczy choćby jej pojawienie się i równocześnie zajęcie wysokiej, trzeciej noty w ogólnopol- 
skim plebiscycie na Słowo Roku 2019, zorganizowanym po raz dziewiąty przez Instytut Języka Polskiego Uniwersytetu Warszawskiego we współpracy z Narodowym Centrum Kultury i Fundacją Języka Polskiego.

W rankingu językoznawców Słowem Roku 2019 został „klimat”. Drugie miejsce zajął skrótowiec „LGBT” odnoszący się do lesbijek, gejów, osób biseksualnych i transpłciowych, a trzecie - słowo „feminatyw”. (www1)

Językoznawcy uznali, że „Klimat” był Słowem Roku 2019. Na drugim miejscu znalazło się „LGBT”, a na trzecim „feminatyw”. Wybór internautów nieznacznie się różni. Ich zdaniem poprzedni rok zdominowało „LGBT”, na drugim miejscu był „klimat”, a na trzecim „hulajnoga”. (www2)

Nie dziwi zatem, że można już nawet odnaleźć wzory paradygmatyki fleksyjnej rzeczownika feminatyw, opisanego jako męskorzeczowy, synonimiczny względem feminatywum (por. www3):

\begin{tabular}{|l|c|c|}
\hline Przypadek & Liczba pojedyncza & Liczba mnoga \\
\hline Mianownik & feminatyw & feminatywy/feminatywa \\
\hline Dopełniacz & feminatywu & feminatywów \\
\hline Celownik & feminatywowi & feminatywom \\
\hline Biernik & feminatyw & feminatywy/feminatywa \\
\hline Narzędnik & feminatywem & feminatywami \\
\hline Miejscownik & feminatywie & feminatywach \\
\hline Wołacz & feminatywie & feminatywy/feminatywa \\
\hline
\end{tabular}

Zdawać się może, iż pojawienie się innowacyjnej formy ten feminatyw wpłynęło na nowe przypisanie rodzajowe łacińskiego feminatywum. Do Poradni Językowej UWr od pewnego czasu zgłaszane są wątpliwości co do rodzaju gramatycznego samego feminatywum. Jeśli chcemy konsekwentnie podążać za jego źródłosłowem łacińskim, to zgodnie z zakończeniem -um zarówno masculinum, jak i feminatywum są rodzaju nijakiego (podobnie jak deminutivum, augmentativum, collectivum, compositum) - i tak w większości naukowych, językoznawczych tekstów polskojęzycznych są one używane. Neologiczne twory: ten feminatyw, także: ten masculatyw, ten neutratyw ujawniają uzualną tendencję do reduplikacji pojęć naukowych, być może w świadomości potocznej lepszych, bo spolszczonych. Z perspektywy naukowego obrazu świata ten feminatyw i tak jawi się jako forma używana bardziej precyzyjnie (jako odpowiednik nazwy żeńskiej/feminatywum) niż powszechnie funkcjonująca w dyskusjach publicznych (niejęzykoznawczych) żeńska końcówka (jako odpowiednik feminatywnego przyrostka). Notujemy niezliczone wystąpienia tej ostatniej:

Polszczyzna jest kobietą: rewolucyjna żeńska końcówka. (www4)

Męska końcówka - żeńska końcówka pół żartem na serio. (www5)

W Internecie toczy się wojna o żeńskie końcówki zawodów. Radykalne środowiska kobiece domagają się żeńskich końcówek. Ich brak oznacza dla nich brak prestiżu. (www6)

Żeńskie końcówki, feminatywy w II RP. Używano ich w Polsce już 100 lat temu i nie wzbudzały kontrowersji. (www7) 
Choć językoznawcy podkreślają, że określenie żeńska końcówka jest funkcjonującym jedynie w obiegu potocznym uproszczeniem, gdyż w lingwistyce mówi się o formantach, przyrostkach czy sufiksach żeńskości, a końcówki są cząstkami fleksyjnymi, nie zaś słowotwórczymi, to właśnie owa nominacja wydaje się w uzusie i tak zwanej wojnie o żeńskie końcówki (Szpyra-Kozłowska 2021; Jankowski, w druku) najczęściej używana, toteż powszechnie zrozumiała, choć z perspektywy językoznawczej oczywiście błędna.

\section{Podsumowanie}

Obecność kontrowersji i sporów wywołanych podnoszeniem problemu tak zwanej językowej i tekstowej niewidzialności kobiet nie tylko w kręgach językoznawczych, akademickich, lecz także w środowiskach niezwiązanych bliżej z lingwistyką powoduje pojawianie się w komunikacji publicznej potocznych użyć czy wręcz wariantów naukowych terminów. W tekstach naukowych oprócz tradycyjnej terminologii naukowej: feminativum/feminatywum, nazwa żeńska zaczyna pojawiać się również neologizm feminatyw (zob. np. Szpyra-Kozłowska 2021), różniący się względem łacińskiego oryginału jedynie stopniem adaptacji do polszczyzny (skądinąd odrzucenie łacińskiej końcówki -um nie jest w procesie adaptacji wyrazów łacińskich do języka polskiego czymś wyjątkowym; por. np. łac. ornamentum - pol. ornament, łac. pactum - pol. pakt, łac. vallum - pol. wat) ${ }^{2}$. Natomiast w potoczno-publicystycznym obiegu komunikacyjnym rekordy popularności bije wyrażenie żeńskie końcówki i choć jest nieprecyzyjne, wielokrotnie przez lingwistów krytykowane za niewłaściwe jego użycie z powodzeniem zastępuje w języku potocznym terminy naukowe. Wszak — jak sformułował tę myśl Józef Wierzchowski (1980: 113-114) — „ani świat rzeczy, ani schematy uzyskiwane przez logikę lub jakąkolwiek inną naukę nie mogą być podstawą wyróżnień dokonywanych w języku”. Owe wyróżnienia, rozumienia, kryteria wyodrębniania i sposoby nazywania tego, co dotyczy nominacji kobiet, niezmiennie ewoluują, przeto nabierają ostrości i precyzji interpretacyjnej. Zauważyć to można zarówno w samych analizach i zaleceniach językoznawczych (por. dwa, dość różne, stanowiska Rady Języka Polskiego przy Prezydium PAN w sprawie żeńskich form nazw zawodów i tytułów: dość zachowawcze, konserwatywne z 19 marca 2012 roku i otwarte, postępowe z 25 listopada 2019 roku), jak i w zmieniającym się stanie świadomości normatywno-językowej użytkowników i użytkowniczek polszczyzny.

2 Morfologię zapożyczeń łacińskich (i greckich) oraz procesy ich adaptacji omawia Danuta Moszyńska (1976). 


\section{Bibliografia}

Batko-Tokarz B. (2012): Klasyfikacja haseł słownikowych do pola tematycznego „płeć”, „Język Polski” 92, nr 3, s. 184-193.

Chlebda W. (1993): Słownik a „dwuoczne postrzeganie świata”, [w:] O definicjach i definiowaniu, red. J. Bartmiński, R. Tokarski, Lublin, s. 195-205.

Doroszewski W. (1928): Monografie słowotwórcze, „Prace Filologiczne” 13, s. 58-165.

Doroszewski W. (1962): O kulturę słowa. Poradnik językowy, Warszawa.

Grochowska M., Wierzbicka A. (2015): Produktywne typy słowotwórcze nazw żeńskich we wspótczesnej polszczyźnie, „Acta Universitatis Lodziensis. Folia Linguistica” 49, s. 45-55.

Grzegorczykowa R. (red.) (1999): Gramatyka współczesnego języka polskiego, t. 2. Morfologia, Warszawa.

Grzegorczykowa R., Puzynina J. (1979): Słowotwórstwo współczesnego języka polskiego. Rzeczowniki sufiksalne rodzime, Warszawa.

Hołojda-Mikulska K. (2019): Problem z potocznościa nazw żeńskich w polszczyźnie XXI wieku, niepublikowana rozprawa doktorska powstała pod kierunkiem Jana Miodka, Instytut Filologii Polskiej Uniwersytetu Wrocławskiego, Wrocław.

Horodeńska-Ostaszewska M. (2006): Nazwy kobiet w „Uniwersalnym słowniku języka polskiego” PWN (2003), „Prace Filologiczne” 51, s. 179-187.

Jadacka H. (2001): System słowotwórczy polszczyzny (1945-2000), Warszawa.

Jankowski H. (w druku): W obronie języka czy w obawie przed zmiana? Manipulacje językowe oraz techniki erystyczne $w$ tekstach publicystycznych o nazwach żeńskich, Łódź.

Karwatowska M., Szpyra-Kozłowska J. (2005): Lingwistyka płci. Ona i on w języku polskim, Lublin.

Klemensiewicz Z. (1957): Tytuły i nazwy zawodowe kobiet w świetle teorii i praktyki, „Język Polski” 37, nr 2, s. 101-119.

Kreja B. (1964): Słowotwórstwo nazw żeńskich we wspótczesnym języku polskim, „Język Polski” 44, nr 3, s. $129-140$.

Krysiak P. (2020): Nazwy żeńskie we współczesnej leksykografii polskiej i francuskiej, Wrocław.

Kupiszewski W. (1967): Tytuły i nazwy zawodowe kobiet, „Poradnik Językowy”, z. 8, s. 371-374.

Łaziński M. (2006): O panach i paniach. Polskie rzeczowniki tytularne a ich asymetria rodzajowo-plciowa, Warszawa.

Małocha-Krupa A. (red.) (2015): Słownik nazw żeńskich polszczyzny, autorki haseł: K. Hołojda, P. Krysiak, A. Małocha-Krupa, M. Śleziak, Wrocław.

Małocha-Krupa A. (2018a): Feminatywum w uwikłaniach językowo-kulturowych, Wrocław.

Małocha-Krupa A. (2018b): Opis leksykograficzny feminatywum. (Nie)możliwości zobiektywizowania, [w:] Między teorią a praktyką. Metody współczesnej leksykografii, t. 1, red. M. Bańko, H. Karaś, Warszawa, s. 151-165.

Moszyńska D. (1976): Morfologia zapożyczeń łacińskich i greckich w staropolszczyźnie, Wrocław.

Nazwy żeńskie od nazw przymiotnikowych?, „Język Polski” 1906, nr 4, s. 55.

Piotrowicz A., Witaszek-Samborska M. (2015): Kilka uwag o nieodnotowanych w słownikach wspótczesnej polszczyzny formacjach feminatywnych, „Poznańskie Spotkania Językoznawcze” 29, s. 87-96.

„Poradnik Językowy” 1906, nr 4.

„Poradnik Językowy” 1907, nr 6-7.

Szpyra-Kozłowska J. (2019): Premiera, premierka czy pani premier? Nowe feminatywy w ujęciu ankietowym, „Język Polski” 99, nr 2, s. 22-40.

Szpyra-Kozłowska J. (w druku): Rektorka, dziekana, kanclerka. Nazwy kobiet zatrudnionych na stanowiskach uniwersyteckich $w$ świetle badania ankietowego, Łódź.

Szpyra-Kozłowska J. (2021): Nianiek, ministra i japonki. Eseje o języku i płci, Kraków. 
Śleziak M. (2018): Prymat leksykograficznego egzemplum i jego konsekwencje dla hasła - na przykładzie „Stownika nazw żeńskich polszczyzny”, [w:] Między teoriq a praktyką. Metody wspótczesnej leksykografii, red. M. Bańko, H. Karaś, Warszawa, s. 245-255.

Wierzchowski J. (1980): Semantyka językoznawcza, Warszawa.

Woźniak E. (2014): Język a emancypacja, feminizm, gender, „Rozprawy Komisji Językowej ŁTN” 60, s. 295-312.

Woźniak E. (2020): Przełomowe dwudziestolecie. Lata 1918-1939 w dziejach języka polskiego, Łódź.

Żarski W. (1992): Feminativa w polszczyźnie mówionej mieszkańców Wrocławia, [w:] Polszczyzna mówiona wrocławian, cz. 2. Studia z zakresu fonetyki i morfologii, Wrocław, s. 125-134.

Żmigrodzki P. (2008): Słowo - słownik - rzeczywistość. Z problemów leksykografii i metaleksykografii, Kraków.

\section{Źródła internetowe}

www1: https://edukacja.dziennik.pl/aktualnosci/artykuly/617066,slowa-roku-2019-klimat-lgbt-feminatyw.html (dostęp: 3.01.2021).

www2: https://www.polsatnews.pl/wiadomosc/2020-01-03/slowo-roku-2019-klimat-lgbt-feminatyw/ (dostęp: 3.01.2021).

www3: https://pl.wiktionary.org/wiki/feminatyw (dostęp: 10.02.2021).

www4: http://culture.pl/pl/artykul/ (dostęp: 1.10.2018).

www5: http://www.sofijon.pl/module/article/one/32 (dostęp: 11.06.2013).

www6: http://www.rp.pl/artykul (dostęp: 29.02.2012).

www7: https://wielkahistoria.pl/zenskie-koncowki-feminatywy (dostęp: 21.11.2019).

\section{Feminativum, feminative, female name, female ending - terminological problems}

Summary

The aim of the article is to present various scopes of functioning and different ways of understanding the terms appearing most often in the Polish literature in relation to feminine nouns naming women. A specific terminological chaos arises from, on the one hand, different, often incompatible definitions of female names/feminatives quoted by language researchers and researchers, and on the other hand, from controversies and disputes observed in non-academic circles over the issue of women's linguistic invisibility. This in turn results in the emergence of colloquial use or even variants of scientific terms in public communication. The authors present the understanding of the term 'female names' developed in the Wrocław research center and characterize it against the background of other concepts. They present terminological assumptions underlying the Dictionary of Polish Female Names (2015). The article also discusses the evolution of the scientific term 'feminative' and its penetration into general Polish, as well as the female ending-based forms that appear in colloquial Polish.

Keywords: feminative, feminative, female name, terminology, gender linguistics. 